\title{
NIETZSCHE Y EL «CONOCIMIENTO DESINTERESADO» DE LOS SOFISTAS
}

\author{
ÚRSULA CARRIÓN CARAVEDO \\ Universidad del Pacífico
}

\begin{abstract}
RESUMEN: El presente trabajo constituye una aproximación a la tradición sofista desde la perspectiva nietzscheana. De modo más específico, analizamos hasta qué punto los planteamientos de los sofistas y la contienda que se desarrolla entre ellos le sirven al filósofo como una herramienta para enfrentarse a la tradición platónica. Para ello, describimos primero ciertas características propias de la competencia entre estos oradores, las cuales resultan compatibles con la valoración nietzscheana del devenir. En segundo lugar, relacionamos la interpretación de Nietzsche del homo mensura con el perspectivismo y el escepticismo propios de su pensamiento. Por último, explicamos cómo la expresión "cultura del conocimiento desinteresado", referida a los sofistas, apunta a marcar un contraste frente a la seriedad de la tradición socrático-platónica contra la que Nietzsche combate.
\end{abstract}

PALABRAS CLAVE: relativismo; perspectivismo; contienda; juego; devenir.

\section{Nietzsche and the "disinterested knowledge» of the sophists}

ABSTRACT: The aim of the present work is to approach the sophist tradition from a Nietzschean perspective. More specifically, we analyze how the sophists and the contest that develops between them serve the philosopher as a tool to confront the Platonic tradition. In order to do that, we first describe certain characteristics of the competition among sophists, which are compatible with the Nietzschean valuation of becoming. Secondly, we relate Nietzsche's interpretation of homo mensura with his perspectivism and skepticism. Finally, we explain how the expression «culture of disinterested knowledge", referred to the sophists, aims to contrast them with the seriousness of the PlatonicSocratic tradition against which Nietzsche fights.

KEY WORDS: relativism; perspectivism; contest; game; becoming.

A lo largo de la obra de Nietzsche es posible encontrar abundantes referencias a la tradición griega en general. Además de El nacimiento de la tragedia, uno de sus más conocidos textos sobre el tema, existe un conjunto de escritos y conferencias sobre literatura y filología clásicas. Algunos de ellos, preparados en la época cercana a la mencionada obra, son El nacimiento del pensamiento trágico, Homero y la filología clásica, El drama musical griego, Sócrates y la tragedia, La visión dionisíaca del mundo y El tratado florentino de Homero y Hesíodo, su origen y su certamen.

Adicionalmente, entre los años 1872 y 1876, Nietzsche impartió en Bayreuth una serie de lecciones sobre los presocráticos que se concretaron en la publicación de Los filósofos preplatónicos. Este texto se complementa con La filosofía en la época trágica de los griegos, desarrollado durante la primavera de 1873. Entre otros escritos de Nietzsche dedicados al estudio de la cultura griega, están El Estado griego y El certamen de Homero. Este último resulta particularmente sugerente en la medida en que el autor analiza la noción de agón, la cual no solo despierta en él un especial interés, sino que constituye un referente fundamental dentro de su obra. 
Además de las mencionadas investigaciones tempranas, Nietzsche dedicó diversas lecciones a la retórica clásica y al análisis de los diálogos platónicos en la Universidad de Basilea. El interés por Platón y Sócrates se revela tanto en dichas lecciones como también en las frecuentes referencias a ellos a lo largo de toda la obra nietzscheana.

Curiosamente, las menciones a los sofistas son más bien limitadas y, por momentos, poco claras. Thomas Brobjer ${ }^{1}$, uno de los pocos estudiosos de la obra de Nietzsche que han abordado su relación con los sofistas, no cree que ellos susciten un especial entusiasmo en el filósofo. Las alusiones nietzscheanas a estos, continúa el autor, resultan ambivalentes: entre los años 1869 y 1873, Nietzsche se mostraba por momentos hostil hacia los sofistas, pero en la década de 1880, su visión se tornó más positiva. Joel Mann², por el contrario, percibe mayor optimismo en la lectura nietzscheana de dichos oradores.

Es presente estudio se inserta en esta discusión orientada a esclarecer la afinidad entre Nietzsche y los sofistas. De modo más específico, indagaremos hasta qué punto los planteamientos de estos oradores y la contienda que se desarrolla entre ellos le sirven al filósofo como una herramienta para combatir la tradición platónica. Para lograr este propósito, describiremos primero ciertos rasgos de la competencia entre sofistas, la cual prioriza la apariencia y la utilidad del discurso. Mostraremos que la lógica detrás de esa lucha es compatible con la valoración nietzscheana del devenir. En segundo lugar, vincularemos la interpretación nietzscheana del homo mensura de Protágoras con el perspectivismo y escepticismo propios de la propuesta de Nietzsche. La tercera parte del presente texto se centrará en el aforismo de Aurora donde aparece la expresión que da título a nuestro trabajo y con la que el autor califica a la tradición sofista: la «cultura del conocimiento desinteresado». Observaremos cómo el espíritu jovial que guía el enfrentamiento entre los sofistas se opone a la seriedad de la tradición socrático platónica, concebida por Nietzsche como la principal responsable del racionalismo y del dogmatismo contra los que él batalla.

\section{LA CONTIENDA SOFISTA}

Se sabe que los sofistas eran maestros de retórica que desempeñaron un papel fundamental en la política de Atenas durante el siglo V a. C. En esa época, el éxito y el renombre del ciudadano residían, principalmente, en su actuación en las asambleas públicas y en su desempeño en las pugnas que tenían lugar en los tribunales, las cuales eran bastante frecuentes ${ }^{3}$. Por ello, una oratoria efectiva, que

1 Brobjer, T., «Nietzsche's Relation to the Greek Sophists», en: Nietzsche Studien, 34, 2005, pp. 256-259.

2 ManN, J., «Nietzsche's Interest and Enthusiasm for the Greek Sophists», en: Nietzsche Studien, 32, 2003, pp. 406-428.

3 Cfr. Robin, L., El pensamiento griego y los orígenes del espíritu científico, México, Uteha, 1956, p. 132-134. 
impresionara a la audiencia, recibía especial valoración ${ }^{4}$. Entonces, para desenvolverse mejor en los debates y erigirse como ganadores de los conflictos, los ciudadanos recurrían a los sofistas, cuyos consejos resultaban particularmente útiles.

También entre los propios sofistas había una competencia constante para aumentar su fama, y sobre ella se pueden encontrar múltiples referencias. Platón, por ejemplo, los concibe en el Sofista como atletas en la lucha argumentativa ${ }^{5}$. Y el personaje de Sócrates, en el Eutidemo, se refiere al orador que da título al diálogo como alguien que había derribado a su contendor y estaba a punto de iniciar el «tercer asalto» ${ }^{6}$. Colli comenta al respecto que «en la retórica cualquier intervención del orador es agonística, ya que los oyentes deberán juzgarla en comparación con lo que digan otros oradores » ${ }^{7}$. Así, la contienda entre estos estaba orientada a persuadir al espectador seduciéndolo con las palabras.

Nietzsche era claramente conocedor de esta tradición. En El certamen de Homero, precisa: «El sofista, el enseñante superior de la Antigüedad, se presenta como un rival frente a otros sofistas» ${ }^{8}$. El autor alemán cita el ejemplo del Protágoras, una obra considerada como una contienda (Wettkampf) en el terreno de la sofística cuya finalidad, en su opinión, consistía en evidenciar la mayor capacidad dialéctica de Sócrates (y de Platón) frente a la de los sofistas ${ }^{9}$.

Merece la pena señalar que el constante perfeccionamiento de la retórica y de su capacidad para persuadir a la audiencia ocasionaba que el triunfo de cada sofista fuera solo provisional; en consecuencia, el poder y el honor conseguidos eran también meramente transitorios. En ese sentido, la lucha entre ellos tenía un carácter lúdico, cercano a otras formas de agón (como los juegos olímpicos o los certámenes entre poetas, por ejemplo). En efecto, si bien el triunfo en una competencia constituye un momento de plenitud y otorga un sentimiento de recompensa por el esfuerzo desplegado, cabe notar, siguiendo la línea de Debra Hawhee ${ }^{10}$, que el sentido originario del agón no es esencialmente teleológico, es decir, no está encaminado hacia la meta exclusiva de ganar un premio. Se trata de un juego, y pese a que la victoria resulte deseable (pues tampoco se trata de competir como quien solo cumple mediocremente con una tarea ${ }^{11}$ ), su principal finalidad es la actividad lúdica en sí misma. En ese contexto, la victoria de cada participante es solo provisional. Para que la competencia no cese, ninguno de los contendores puede adquirir una hegemonía absoluta y anular, de modo definitivo, a los demás.

\footnotetext{
4 McIntyre, A., Historia de la ética, Barcelona, Paidós, 1996, pp. 24-34.

5 Platón, Sofista, 231e.

6 Platón, Eutidemo, 277d.

7 Colli, G., El nacimiento de la filosofía, Barcelona, Tusquets editores, 2000, p. 106.

8 KSA 1, 790 (El certamen de Homero, en: Nietzsche, Friedrich, Obras completas, I, p. $566)$.

KGW II, 4, 122. Véase también Brobjer, Thomas, op. cit., p. 270.

10 Hawhee, D., «Agonism and Arete», en: Philosophy and Rethoric, Núm. 3, Vol. 35, 2002, pp. 185-207.

${ }_{11}$ Véase al respecto Acampora, C. D., «Demos Agonistes Redux. Reflections on the Streit of Political Agonism», en: Nietzsche-Studien, 32, 2003, p. 379.
} 
Así, parafraseando a Nietzsche, el agón anhela, como medio de protección contra el genio, un segundo genio ${ }^{12}$. El filósofo alemán incluso interpreta el ostracismo como la necesidad de apartar a los que sobresalen demasiado para no poner en riesgo la continuidad de la lucha. En El certamen de Homero, recuerda el comentario de los efesios luego de que desterraran a Hermodoro:

Entre nosotros nadie debe ser el mejor; pero si lo es alguno, que lo sea en otro sitio y entre otros'. Pero ¿por qué ninguno debe ser el mejor? Porque con ello ya no habría certamen, y el eterno fundamento vital del Estado griego estaría en peligro. ${ }^{13}$

Nietzsche cree entonces que detrás del ostracismo hay un interés por seguir estimulando el combate. Y este último, como revela la cita, cumple un rol central en el Estado griego, de modo que su preservación es necesaria. El agón constituye así un fundamento vital del Estado, piensa el filósofo, en tanto abre posibilidades para que sobresalgan los individuos y se dinamicen y renueven las sociedades.

Pero regresemos a los sofistas. Se suele considerar que su preocupación central se orientaba principalmente hacia la forma del discurso y no tanto hacia el contenido del mismo. Siguiendo esa línea, Nietzsche señala que las enseñanzas de estos oradores podían servir para ayudar a ganar causas débiles ${ }^{14}$. En Humano demasiado humano, menciona a los sofistas de la era poscristiana, quienes «se dirigen a almas huecas, ávidas de apariencias, de resonancias y de efectos ${ }^{15}$. Ciertamente, esos no son los mismos del siglo V a. C. Sin embargo, no parece casual que Nietzsche califique a otros pensadores como sofistas; creemos que lo hace justamente porque encuentra en ellos una predilección por la apariencia y el efecto (y no tanto por el fondo o el contenido del pensamiento).

El gusto por la belleza formal del discurso se contrapone a la actitud de filósofos de la época como Sócrates y Platón, considerados por nuestro autor pensadores carentes de sensibilidad y de una perspectiva artística ${ }^{16}$. Un ejemplo puntual que da Nietzsche se encuentra en su «Historia de la elocuencia griega». Allí menciona a Trasímaco: lo describe como un técnico de la retórica que le dio especial importancia al ritmo y que fue víctima de una caricaturización por parte de Platón, quien lo presentó como un personaje arrogante y corrupto en la República ${ }^{17}$.

No había, pues, en los sofistas una preocupación por la búsqueda de la verdad, sino por aquello que resultara útil o conveniente. Como solían viajar mucho, notaron que los códigos de conducta no eran universales, sino que dependían del contexto donde estaban insertos. Por ello defendían el relativismo, resumido en la famosa frase de Protágoras que distingue al ser humano como medida de todas las cosas. La máxima del pensador de Abdera implica no solo que las cualidades sensibles son relativas a la persona que las juzga, sino también que las creencias tienen

\footnotetext{
12 KSA 1, 789 (El certamen de Homero, p. 566).

13 KSA 1, 788 (Ibid., p. 565).

14 Nietzsche, F., «Historia de la elocuencia griega», en: Obras completas, II, Madrid, Tecnos, 2013, p. 899.

15 KSA 2, 474 (Humano, demasiado humano, II, §221, pp. 73-74).

16 Nietzsche, F., «Historia de la elocuencia griega», p. 899.

17 Ibid., p. 902.
} 
un valor restringido a las comunidades en que están insertas. Así, no hay criterios absolutos que determinen la validez universal de algún juicio. Como consecuencia de ese punto de vista, la competencia entre sofistas confería prioridad a la eficacia del discurso, teniendo siempre en cuenta la particularidad de cada contexto.

La propuesta de Protágoras, según Nietzsche, es heredera tanto de Heráclito como de Demócrito ${ }^{18}$. Sobre este último, nuestro autor recuerda la tesis según la cual las cualidades sensibles (lo dulce, lo amargo, el color) se dan únicamente por convención, dado que la realidad en sí misma es solo átomos y vacío ${ }^{19}$. Así, no habría nada esencialmente dulce ni salado; y la asignación de rasgos como esos sería únicamente producto de un acuerdo humano, tal como se desprende también de la máxima de Protágoras.

Por su parte, a Heráclito se le atribuyen fragmentos donde señala que el calor y el frío se intercambian mutuamente o que el camino hacia arriba y hacia abajo son el mismo ${ }^{20}$. Esas sentencias parecen servir de inspiración para los sofistas, quienes no conciben categorías fijas, absolutas o inherentes a las cosas. Nietzsche considera que el pensador de Éfeso le confiere un especial predominio al cambio y la multiplicidad, producto del polemos que gobierna todo. Parafraseando a Heráclito, lo hace decir: «No veo más que devenir [...] incluso la corriente en la que os bañáis por segunda vez, ya no es la misma en la que os bañasteis la vez anterior» ${ }^{21}$. Evidentemente, Nietzsche está aludiendo aquí al famoso fragmento B 12: «Sobre quienes se bañan en los mismos ríos afluyen aguas distintas y otras distintas ${ }^{22}$. La realidad está marcada por un dinamismo inherente; y el río es como la vida misma, que está en constante renovación.

Resulta interesante que también Platón, en su momento, haya vinculado a los sofistas con la propuesta de Heráclito. Veamos el siguiente pasaje del Fedón:

...y sobre todos los que se dedican a los razonamientos contrapuestos, sabes que acaban por creerse sapientísimos y por sentenciar por sí solos que en las cosas no hay ninguna sana ni firme ni tampoco en los razonamientos, sino que todas las

18 Cfr. Nietzsche, F., «Aus dem Nachlass der Achtzigerjahre», en: Werke in drei Bänden, III (ed. Karl Schlechta), p. 757.

19 KGW II 4, 333 (Los filósofos preplatónicos, p. 146).

20 Véanse los fragmentos B 60 y el B 126.

21 KSA 1, 823 (La filosofía en la época trágica de los griegos, p. 58).

22 Usamos la traducción de Eggers, Conrado y Victoria Juliá Los filósofos presocráticos, Tomo I, Madrid, Gredos, 1978, p. 382. Al parecer Nietzsche accedió a la versión del fragmento de Heráclito que está en el Crátilo de Platón y que, durante mucho tiempo, se le atribuyó al presocrático. En efecto, el pasaje del mencionado diálogo señala lo siguiente: En algún sitio dice Heráclito "todo se mueve y nada permanece" y, comparando los seres con la corriente de un río, añade "no podrías sumergirte dos veces en el mismo río"». Platón, Crátilo, 402a. Conrado Eggers y Victoria Juliá apuntan —en línea con otros intérpretes- que las dos sentencias son apócrifas (op. cit., p. 395). Esta versión del fragmento del río, a diferencia la que hemos citado como B 12, otorga mucho mayor énfasis al devenir. Sin embargo, no llega a ser tan radical como la propuesta que Nietzsche atribuye al propio Crátilo: este, dice el filósofo, «superó al maestro, que sostenía que uno no puede bañarse dos veces en el mismo río, con la afirmación de que ni siquiera una sola vez podría ocurrir esto». (KGW II 4, 43 / «Introducción al estudio de los Diálogos de Platón», en: Nietzsche, F., Obras completas, II, Diego Sánchez Meca (ed.), Madrid: Tecnos, 2013, p. 468). 
cosas sin más van y vienen arriba y abajo, como las aguas del Euripo, y ninguna permanece ningún tiempo en nada ${ }^{23}$.

Los primeros a los que se refiere el texto parecen ser los sofistas, en tanto desconfiaban de la existencia de cualidades inherentes a las cosas y empleaban, en sus discursos, argumentos contrarios. Platón asocia esa visión sofista con el ya mencionado fragmento del pensador de Éfeso sobre el río. Así, el filósofo ateniense parece encontrar en la importancia que Heráclito otorga al devenir un antecedente al relativismo ${ }^{24}$.

Inspirado por los fragmentos de Heráclito, Nietzsche considera que las cosas solo devienen y no permanecen idénticas: "no son sino el relampagueo y chispazos que originan las espadas que entrechocan en combate, son el fulgor de la victoria en la lucha de las cualidades contrarias» ${ }^{25}$. En ese sentido, las pretensiones del intelecto por establecer categorías estables y unívocas son solo estrategias que emplea el ser humano para engañarse a sí mismo y olvidarse de la transitoriedad. Atendiendo a esas motivaciones, añade en Sobre verdad y mentira en sentido extramoral ${ }^{26}$, muchos desean que desaparezca la lucha y anhelan un tratado de paz; es decir, pretenden que se fije la verdad de manera absoluta, clara y permanente.

EL HOMO MENSURA, EL PERSPECTIVISMO Y EL ESCEPTICISMO

Hemos señalado que el predominio del devenir que Nietzsche atribuye a Heráclito y la convencionalidad de las cualidades que resalta en Demócrito confluyen, a su juicio, en el planteamiento de Protágoras (y en el de la mayoría de sofistas). La visión nietzscheana sobre ellos hace posible ubicarlos cerca del perspectivismo, que no es sino la capacidad de adoptar múltiples miradas de la realidad en general. Al respecto, Joel Mann ${ }^{27}$ estima que el principio del homo mensura le sirve a Nietzsche como una herramienta crítica para sostener que las cosas, antes de ser evaluadas, tienen un valor neutro. En ese sentido, no reconocer el perspectivismo constituye una forma de desvirtuar el mencionado principio.

El perspectivismo plantea como necesario admitir la condición de interpretación de cualquier postura. En consecuencia, no se puede exigir que algún punto de vista sea aceptado incondicionalmente. Al saber que se trata de una percepción particular o propia, el perspectivista no intenta imponer a otros sus creencias ${ }^{28}$. De alguna manera, el mundo se ha vuelto infinito para nosotros «en la medida en que no podemos rechazar la posibilidad de que él incluye dentro de sí infinitas

23 Platón, Fedón, 90 b-c.

${ }^{24}$ No es esta la ocasión, sin embargo, para discutir hasta qué punto las interpretaciones de Nietzsche o Platón sobre Heráclito son precisas. Basta señalar que difícilmente el filósofo de Éfeso podría considerarse un relativista en la medida en que sugiere que existe una verdad, la cual demanda al ser humano el reconocimiento de un logos que gobierna a todas las cosas.

25 KSA 1, 826 (La filosofía en la época trágica de los griegos, p. 62).

26 KSA 1, 882-884 (Sobre verdad y mentira en sentido extramoral, pp. 19-21).

27 ManN, J., op. cit., pp. 418-421.

28 Cfr. Nehamas, A., Nietzsche, la vida como literatura, Madrid, Turner F.C.E., 2002, p. 90. 
interpretaciones $»^{29}$, manifiesta Nietzsche. El perspectivismo implica entonces renunciar a la pretensión de que haya una postura particular que revele una imagen más fidedigna del mundo tal y como es.

A diferencia de Joel Mann, Thomas Brobjer ${ }^{30}$ no encuentra mayor interés en Nietzsche por el principio del homo mensura. En su opinión, los comentarios que realiza el profesor de Basilea sobre el Teeteto ${ }^{31}$ son una muestra de ello. En dicho diálogo, Sócrates cuestiona expresamente la sentencia de Protágoras; sin embargo, Nietzsche no refuta las objeciones socráticas. No obstante, que el filósofo alemán no realice una defensa del homo mensura o que no revele una fascinación particular por este no impide, a nuestro juicio, encontrar vínculos entre el mencionado principio y el perspectivismo nietzscheano.

Ahora bien, Brobjer no solo alude al desinterés nietzscheano por la máxima sofista. Advierte además que el homo mensura puede derivar en un antropocentrismo en tanto se concibe al ser humano como el eje desde el cual se otorga valor y se emiten juicios sobre las cosas. Sin embargo, Nietzsche, como adecuadamente nota el autor, toma distancia de dicho antropocentrismo. En efecto, si uno revisa, por ejemplo, La ciencia jovial, § $346^{32}$, encuentra una crítica severa hacia el hombre orgulloso, que se cree el juez de todas las cosas. Algo análogo sucede en Sobre verdad y mentira en un sentido extramoral ${ }^{33}$. Allí se cuestiona la concepción del hombre como medida de todo y del intelecto como juez de todas las cosas. Nietzsche critica enfáticamente las pretensiones de la razón humana, que tiende a no reconocer sus límites. Nuestro intelecto fija conceptos y categorías para olvidar que somos efímeros. De algún modo, considera el filósofo, nos mantiene en un estado de engaño, pues hay un fondo oscuro en el ser humano que no puede ser completamente conocido.

Creemos que las limitaciones de la razón humana a las que alude Nietzsche son perfectamente compatibles con el homo mensura de Protágoras, pues a partir de este principio se objeta que haya alguien capaz de acceder a una verdad absoluta. Tanto él como otros sofistas parecen ser conscientes de los límites humanos y por ello recusan la posibilidad de que exista una mirada indiscutiblemente objetiva sobre el mundo. Los sofistas suelen mantenerse escépticos frente a las certezas y a la posibilidad de dar cuenta, de modo cabal, de toda la realidad. Para Protágoras, es solo desde nuestra perspectiva humana que podemos hablar sobre el mundo. En ese sentido, la contienda entre los oradores parece estar guiada por un espíritu jovial, que no pretende fijar creencias absolutas. Esto le confiere, como ya adelantamos, un carácter provisional, lúdico. Al no buscar el descubrimiento de una verdad plena, el saber sofista, nota Nietzsche, se reduce al terreno de la mera opinión ${ }^{34}$.

Siguiendo esa misma línea se ubica Gorgias. El orador de Leontini supone que nada existe y que, si existiera, sería incognoscible e incomunicable. En efecto, lo que los seres humanos comunicamos son solo palabras (no percepciones directas




de las cosas); y esas palabras no logran transmitir propiamente nuestras sensaciones $^{35}$. Con esta propuesta, Gorgias destruye todo criterio de verdad, pues, ¿cómo juzgar aquello que ni existe ni puede ser comunicado?

Estas últimas consideraciones aproximan a los sofistas a la concepción nietzscheana del lenguaje presente en su texto Sobre verdad y mentira en un sentido extramoral. El lenguaje, dice el filósofo, tiene una relación mínima con la esencia de las cosas; no designa la realidad directamente. Entre el sujeto y el objeto no existe un nexo de causalidad ni de exactitud, sino una conducta estética: el ser humano construye recurrentemente metáforas para vincularse con el mundo y con los demás. Y dichas metáforas, en opinión de Nietzsche, no se reducen a un significado unívoco; carecen de un sentido propio u objetivo.

La calificación del lenguaje como metafórico le servirá al filósofo no solo para destruir las certezas de la razón, sino también como una estrategia dentro de su propia filosofía. En ese punto cabe advertir que, si Nietzsche es consecuente con su visión perspectivista de la realidad, entonces es consciente de que la suya es solo una entre tantas interpretaciones sobre el mundo. Tendría, pues, que renunciar a la pretensión de que su punto de vista sea aceptado de modo incondicional y absoluto.

Quizá la clave para averiguar si Nietzsche estaría dispuesto a ello radique en la calificación del filósofo como pretendiente de la verdad ${ }^{36}$. El filósofo tiene el deseo o la aspiración hacia la sabiduría, pero no la certeza de poseerla. «Elevado por ella [la fantasía], [el pensamiento filosófico] salta sucesivamente de posibilidad en posibilidad, las cuales serán tomadas provisionalmente por certidumbres [Sicherheiten $]^{37}$, señala Nietzsche. Así, las seguridades a las que accede el pensamiento filosófico son solo probables; tienen un carácter provisional, como la victoria de los competidores del agón.

Asumir el perspectivismo implica adicionalmente que uno mismo pueda oponerse a sus propios puntos de vista en ciertos momentos. «iNunca dejes de decirte a ti mismo o te calles nada que pueda oponerse a tus ideas! Promételo, porque esto forma parte de la honradez exigida, ante todo, al pensador. También es preciso que hagas diariamente campaña contra ti mismo» ${ }^{38}$, manifiesta el autor de Aurora. En efecto, aprender a luchar contra uno mismo es necesario, principalmente para alguien que se dedica a la labor filosófica. El propio Nietzsche reconoce haber llegado a su verdad por muchos caminos diferentes ${ }^{39}$.

[El verdadero filósofo] tiene que haber sido tal vez crítico y escéptico y dogmático e historiador $\mathrm{y}$, además, poeta y coleccionista y viajero y adivinador de enigmas y moralista y vidente y «espíritu libre» y casi todas las cosas, a fin de recorrer el círculo entero de los valores y de los sentimientos valorativos del hombre y a fin de poder mirar con muchos ojos y conciencias, desde la altura hacia toda

35 Gorgias, Fragmentos y testimonios, Buenos Aires, Aguilar, 1974, pp. 43-105.

36 KSA 5, 11 (Más allá del bien y del mal, p. 19).

37 KSA 1, 814. La traducción es nuestra.

38 KSA 3, 244 (Aurora, § 370, p. 232).

39 Cfr. KSA 4, 245 (Así habló Zaratustra, p. 276), también KSA 6, 264 (Ecce homo, p. 25). 
la lejanía, desde la profundidad hacia toda altura, desde el rincón hacia toda la amplitud $^{40}$.

Para tener una visión diversificada de la realidad, el filósofo debe recorrer diversos senderos y no tomarse muy en serio sus propios puntos de vista. Nietzsche considera, por ejemplo, que el conocedor de su obra Así habló Zaratustra solo puede ser alguien a quien cada una de sus palabras le haya encantado algunas veces y en otros momentos le haya herido profundamente ${ }^{41}$.

La multiplicidad de modos de vida resulta valiosa en la medida en que se traduce en una manera de hacer filosofía más jovial. «De allí la posibilidad de las diversas máscaras que tiene el filósofo artista, lo que implica la posibilidad de adoptar diversas perspectivas para enfrentarse con los problemas y conflictos, sin quedarse en ninguna última o definitiva ${ }^{42}$, comenta al respecto Mónica Cragnolini. Nietzsche parece encontrar en la filosofía la posibilidad del disfraz. Sloterdijk añade que entre sus rostros están el filósofo, el psicólogo, el crítico del conocimiento; incluso Apolo y Dioniso, a través de los cuales expresa una existencia dual ${ }^{43}$. Por su parte, el autor de Ecce homo reconoce que también Wagner y Schopenhauer son figuras que le ayudan a expresar algo sobre sí mismo ${ }^{44}$. En general, Nietzsche emplea a otros personajes como máscaras bajo las que esconde múltiples miradas ${ }^{45}$.

Ahora bien, la diversidad de perspectivas parece reclamar una variedad de herramientas expresivas, de las que Nietzsche hace uso a lo largo de su obra: aforismos, poemas, símiles, metáforas, enigmas, etc ${ }^{46}$. Mediante ellos, juega como un artista creador. De modo particular, las metáforas permiten la renovación fecunda de ideas; hacen posible dar pie a una variedad de interpretaciones, multiplicar las perspectivas, eludir los significados últimos y romper con la univocidad de los conceptos, como bien indica Cragnolini ${ }^{47}$. «Nietzsche está cuestionando la idea de que el conocimiento humano pueda ser retrotraído a unos principios eternos e inmutables y, más aún, que su sentido dependa de tal reducción ${ }^{48}$, agrega al respecto Daniel Innerarity. Al ser una forma de generar nuevos significados, la metáfora impide que nuestra relación vital con el mundo se reduzca o empobrezca.

Emplear múltiples disfraces constituye una estrategia útil para el filósofo alemán: le permite mantener la contienda siempre vigente y también reinventarse a sí mismo. De esta forma, se distancia del dogmatismo recurrente entre sus contemporáneos. Nietzsche encuentra en ellos una tendencia a considerar sus opiniones

40 KSA 5, 144 (Más allá del bien y del mal, § 211, p. 166). Véase también KSA 5, 360-361 (La genealogía de la moral, pp.149-150).

${ }_{41}$ KSA 5, 255 (La genealogía de la moral, p. 30).

42 Cragnolini, M., Nietzsche, camino y demora, Buenos Aires, Biblos, 2003, pp. 226-227.

43 SloterdiJK, P., El pensador en escena: el materialismo de Nietzsche, Valencia: PreTextos, 2000, pp. 73-75.

44 KSA 6, 320 (Ecce Homo, pp. 87-88).

45 Cfr. Colli, G., Después de Nietzsche, Barcelona: Anagrama, 2000, pp. 60-61.

46 Nehamas, A., op. cit., pp. 36-37.

47 Cragnolini, M., op. cit., pp. 235-237.

48 InNerarity D., «La seducción del lenguaje: Nietzsche y la metáfora», en: Contrastes, vol. III, 1998, p. 141. 
como verdades absolutas, irrefutables y universales ${ }^{49}$. Su comportamiento responde al de un espíritu serio y cansado. Un pensador así no admite oponentes; en vez de ellos, "quiere partidarios declarados, camaradas sin escrúpulos, tropas auxiliares, heraldos, un cortejo pomposo ${ }^{50}$. Filósofos de esa clase son como momias ${ }^{51}$ convencidas de poseer una verdad única.

En suma, Nietzsche combate contra su tradición desde diversos frentes y recurre a una variedad de perspectivas. Su única certeza en este enfrentamiento radica en la idea según la cual ninguna de dichas perspectivas debe ser tomada incondicionalmente: la victoria de una de ellas solo puede aspirar a ser pasajera. En ese sentido, el pensador alemán parece respetar la regla básica inherente a toda lógica agonal: la transitoriedad del triunfo de los contendores.

\section{LA CULTURA DEL CONOCIMIENTO DESINTERESADO}

Como adelantamos hace un momento, Nietzsche vincula el perspectivismo y el escepticismo de los sofistas con cierta laxitud respecto de las leyes morales y las costumbres. De hecho, les atribuye un examen de las motivaciones de la moral mediante el cual se concluye que toda moralidad puede justificarse dialécticamente, es decir, que no existe nada bueno en sí mismo ${ }^{52}$. Nuestro autor contrapone la dialéctica platónica, orientada hacia el bien, con la retórica sofista, que constituye un camino hacia la inmoralidad ${ }^{53}$. Así lo formula en el parágrafo 168 de Aurora, donde señala lo siguiente: «sospechamos que esa cultura, combatida por Platón y por todas las escuelas socráticas, debió ser muy inmoral» ${ }^{54}$.

Resulta interesante, a propósito de esta calificación de «inmoral», la discusión entre Thomas Brobjer ${ }^{55}$ y Joel Mann ${ }^{56}$ sobre el mencionado texto. Ambos se preguntan quién es el sujeto de ese «sospechamos». ¿Se está incluyendo Nietzsche en el grupo de los que atribuyen inmoralidad a los sofistas? Brobjer precisa que con ese «nosotros», Nietzsche se está refiriendo a «los modernos» (sin incluirse), mientras Mann opina que se trata de un «yo, Nietzsche». Para el primer autor, que Nietzsche se excluya indica que no está de acuerdo con que Platón clasifique a los sofistas de inmorales. Por el contrario, continúa Brobjer, el filósofo alemán alaba la cultura a la cual pertenecen tanto los sofistas como Tucídides ${ }^{57}$. En esa misma línea de

49 Cfr. KSA 5, 60 (Más allá del bien y del mal, §43, p. 71).

50 KSA 3, 312 (Aurora, §542, p. 283).

51 Cfr. KSA 6, 75 (Crepúsculo de los ídolos, p. 52).

52 Nietzsche, F., «Aus dem Nachlass der Achtzigerjahre», en: Werke in drei Bänden, III (ed. Karl Schlechta), p. 757.

53 Ibid, p. 517

$54 \quad$ KSA 3, 151.

55 Brobjer, T., op. cit., pp. 257-277.

56 ManN, J., op. cit., pp. 406-428.

57 Es verdad, como nota Brobjer (op. cit, pp. 264-266), que es discutible categorizar a Tucídides como un sofista propiamente. No obstante, escapa del alcance de esta investigación detenernos en la pertinencia de dicha clasificación. 
interpretación se sitúa Arnaud Sorosina ${ }^{58}$, quien ve en Tucídides al mayor de los sofistas en la medida en que encarna una interpretación inmoralista del mundo. Esta, cabe advertir, no consiste en una apología del mal, sino en una forma de rechazo a la propuesta moral platónica. En ese sentido, los sofistas se convertirían en posibles aliados del antiplatonismo nietzscheano.

Nos parece manifiesto, siguiendo la línea de Brobjer, el ánimo positivo con que Nietzsche se refiere a los sofistas en el pasaje citado. No obstante, creemos que en caso Mann tuviera razón y Nietzsche se incluyera en el grupo que califica a la cultura sofista como inmoral, quizá lo estaría haciendo justamente con un tono positivo, es decir, como para confrontarla con el platonismo contra el que nuestro autor combate. Así, que los sofistas sean inmorales no constituiría un reproche hacia ellos. Por el contrario, significaría que son antiplatónicos y que se alejan de las categorías fijas en torno al bien y el mal.

En el citado parágrafo de Aurora, Nietzsche denomina a los sofistas maestros de la «cultura del conocimiento desinteresado». Inmediatamente después, asocia esa cultura a tres elementos: la alegría; una justicia práctica mayor que la de Platón; y una actitud que, antes de calumniar o empequeñecer a quienes considera desagradables, les busca algo rescatable ${ }^{59}$. Indagaremos a continuación en ellos.

Empecemos por la alegría. ¿Por qué Nietzsche asocia esta cualidad con la sofística? Probablemente el sentido de dicha relación apunte a enfatizar el carácter más lúdico que parece guiar la contienda entre los oradores, frente a la seriedad de la dialéctica de Platón, a la que juzga dogmática. El autor alemán contrapone el idealismo platónico al realismo de los sofistas. En el Crepúsculo de los ídolos, sentencia: "la cultura de los sofistas, quiero decir, la cultura de los realistas: ese inestimable movimiento en medio de la patraña de la moral y del ideal propio de las escuelas socráticas ${ }^{60}$. Platón es visto como un pensador cansado y cobarde: niega la vida y plantea un escape de la realidad transitoria y cambiante; para ello, postula un ámbito ideal, superior y permanente. Así, su propuesta se ubica en las antípodas de una actitud vital, jovial, lúdica.

En este punto cabe recordar que Nietzsche considera al socratismo como responsable del fin de la tragedia. En ella, lo apolíneo y dionisiaco juegan, luchan continuamente sin que uno se imponga al otro. Son impulsos generadores del devenir, que «marchan uno al lado del otro, casi siempre en abierta discordia entre sí y excitándose mutuamente a dar luz frutos nuevos y cada vez más vigorosos, para perpetuar en ellos la lucha de aquella antítesis» ${ }^{61}$. El socratismo acaba con la tragedia porque anula ese agón incesante entre ellos. Somete todos los fenómenos al análisis racional, al terreno de la conciencia; a su vez, niega el lado desgarrador de la existencia. El espectáculo trágico se torna, así, frío; el éxtasis se anula ante el predominio del drama racional ${ }^{62}$. El espíritu socrático invade la escena, rompe la

58 Sorosina, A., «O estatuto dos sofistas em Nietzsche», en: Estudos Nietzsche, Espírito Santo, vol. 6, n. 2, 2015, p. 214.

59 KSA 3, 151 (Aurora, pp. 164-165).

60 KSA 6, 156 (Crepúsculo de los ídolos, p. 139-140).

${ }_{61}$ KSA 1, 25 (El nacimiento de la tragedia, p. 41).

62 Cfr. Nachlass, 1869, 1 (2) / KSA 7, 11. 
dinámica del juego del devenir y plantea el conocimiento como única vía de acceso a la virtud y la felicidad ${ }^{63}$.

Resulta pertinente, a propósito de la contraposición entre el socratismo y la sofística, reproducir el final del aforismo 351 de La ciencia jovial:

La modestia fue la que inventó en Grecia la palabra «filósofo», y dejó a los actores del espíritu [Schauspieler des Geistes] la soberbia petulancia de llamarse a sí mismos sabios - la modestia de aquellos monstruos del orgullo y de la autoridad, tales como Pitágoras, como Platón ${ }^{64}$.

Thomas Brobjer ${ }^{65}$ encuentra en este pasaje una muestra de la visión desinteresada -o incluso negativa- de Nietzsche hacia los sofistas. De hecho, la calificación de «actores del espíritu» y la soberbia que les atribuye parecen ir en esa línea. Sin embargo, Joel Mann ${ }^{66}$ opina que se trata de una forma caricaturesca de referirse a los sofistas para exponer la hipocresía de Platón. Consideramos que Mann tiene razón. Efectivamente, resulta irónico que alguien a quien Nietzsche califica como un monstruo del orgullo se considere a sí mismo modesto. Parecería entonces que, desde la mirada nietzscheana, es una falsa modestia la que llevó a Platón a concebirse como un mero "amante de la sabiduría». En otras palabras, Platón es visto como un monstruo soberbio (serio y dogmático) que no les dejó a los sofistas otra alternativa que llamarse a sí mismos «sabios». En ese sentido, el fragmento citado podría leerse como alineado con la contraposición nietzscheana que acabamos de exponer entre ellos y Platón.

Dos pasajes adicionales, extraídos de La ciencia jovial, contribuyen a reforzar esta interpretación. Joel Mann recuerda el § 149. En él, Nietzsche asocia a Platón con la moral sacerdotal, caracterizada por brindar esperanzas a las personas a partir de la creencia en ciertos ideales. En la misma línea está el aforismo 377 del mismo texto. Allí Nietzsche resalta su rechazo hacia los ideales que se postulan como fijos y duraderos (análogos a los de la propuesta platónica). Al mismo tiempo, resalta la vida intempestiva, el amor por el peligro y, en general, las actitudes propias de una gaya ciencia. En suma, la jovialidad y la alegría que Nietzsche vincula con la cultura sofista se confrontan con la seriedad y el orgullo propios del idealismo platónico.

El segundo elemento que Nietzsche relaciona con los sofistas es la justicia práctica, producto del énfasis que ellos le otorgan a la experiencia. Al mostrarse escépticos frente a los principios que se asumen como permanentes y universales, entienden ley como un simple acuerdo humano susceptible de ser modificado ${ }^{67}$. Aquí podría residir, en parte, el componente fructífero asociado a toda contienda agonal. En efecto, si la visión de los sofistas prioriza la práctica o efectividad, la confrontación entre ellos termina siendo productiva pues permite renovar constantemente normas o medidas en función de su utilidad para la polis.

63 Cfr. KSA 1, 94 (El nacimiento de la tragedia, p 128).

64 KSA 3, 558 (La ciencia jovial, p. 215).

65 BrobJer, T., «Nietzsche's Disinterest and Ambivalence toward the Greek Sophists», en: International Studies in Philosophy, 23, 2001, p. 9.

${ }_{66}$ ManN, J., op. cit., pp. 415-417.

67 Cfr. McIntyre, A., op. cit., p. 26. 
Vale la pena observar que, en Los filósofos preplatónicos, Nietzsche también le otorga a la tradición de Sócrates y Platón el calificativo de "práctica ${ }^{68}$. No obstante, creemos que lo hace en un sentido radicalmente distinto. La filosofía socrática es práctica en la medida en que promueve una forma de conocimiento encaminada hacia el bien; en otras palabras, la dialéctica debe tener un correlato en las acciones humanas. Sin embargo, el conocimiento socrático, insistimos, está orientado hacia entidades universales y eternas; es decir, es opuesto al relativismo propio de los sofistas. Lamentablemente, piensa Nietzsche, la hegemonía del socratismo, además de originar el decaimiento de la culura griega, instaura un modo de pensar que se extiende hasta la época Moderna. En ella predominan la ciencia, la razón y la lógica, subordinadas a la búsqueda de certezas absolutas.

El último de los tres elementos mencionados (la actitud de no desdeñar a quien le desagrada y, más bien, buscarle algo rescatable) confirma el carácter lúdico de la contienda sofista. Un rasgo clásico de los certámenes es el respeto por las normas que los rigen. En ese sentido es posible hablar de cierta seriedad implícita en el juego, como bien nota De Santiago Guervós: «no es el jugador el que define el juego, sino el juego el que define a los jugadores ${ }^{69}$. Estos se entregan al ritmo de aquel, lo cual supone la aceptación de sus reglas. Para explicar el respeto por los principios de la competencia, Herman Siemens alude a la idea de simetría: si se quiere que haya una pluralidad de fuerzas en confrontación, es necesaria una comunidad que acepte las reglas de juego ${ }^{70}$. En la lógica del agón, alcanzar la mesura o el control es fundamental.

Nietzsche reconoce en la base del agón a la buena Eris de Hesíodo. «La Éride buena imperaba, en efecto, desde antiguo en todas las actuaciones de las musas ${ }^{71}$, apunta nuestro autor. Esta divinidad motivaba a los griegos a competir para superarse y no a destruir al otro ${ }^{72}$. En ese sentido, los encaminaba hacia el cumplimiento de las normas de combate. El agón puede concebirse entonces como un escenario de provocación y fortalecimiento de los participantes, y no solo como un pretexto para el debilitamiento del oponente, como señala Herman Siemens ${ }^{73}$. De esta manera, la victoria de cada uno de los contendores deja siempre abierta la posibilidad de que el provisional perdedor busque su oportunidad para sobresalir $\mathrm{y}$, entonces, se reanude el enfrentamiento.

68 Cfr. KGW II, 4, 354.

69 De Santiago Guervós, L. E., «La dimensión del juego en la filosofía de Fiedrich Nietzsche», en: Fernández, E. (ed.), Nietzsche y lo trágico, Madrid, Trotta, 2012, p. 215.

70 Siemens, H., «Nietzsche's Agon with Ressentiment: Towards a Therapeutic Reading of Critical Transvaluation», en: Continental philosophy review, Norwell, Vol. XXXIV, 2001, p. 78.

${ }^{71}$ KSA 1, 545 («Sócrates y la tragedia», en: El nacimiento de la tragedia, p. 239). Véase sobre el tema Carrión, Úrsula, «La buena Eris. Reflexiones en torno a la lógica agonal en Heráclito y Nietzsche», en: Instantes y azares. Escrituras nietzscheanas, Buenos Aires, Año XII, N${ }^{\circ} 10,2012$, pp. 37-54.

72 KSA 1, 787. Cfr. Birnbaum, A., Nietzsche. Las aventuras del heroísmo, México D.F., F.C.E., 2004, p. 145.

73 Siemens, H., "Agonal configurations in the Unzeitgemäße Betrachtungen. Identity, Mimesis and the Übertragung of cultures in Nietzsche's early thought», en: Nietzsche Studien, 30, 2001, p. 83. 
Nos parece que esta idea es bastante consecuente con el perspectivismo nietzscheano, pues supone reconocer la provisionalidad de las miradas y valoraciones humanas. Ya hemos visto que el propio Nietzsche se refiere al pensamiento filosófico como un salto sucesivo entre posibilidades, y advierte que cada una de estas constituye una certidumbre meramente provisional. Con ello, nuestro filósofo revela una visión opuesta a las pretensiones dogmáticas tan recurrentes en la Modernidad.

Los tres rasgos que acabamos de comentar contribuyen a comprender mejor la concepción de los sofistas como exponentes de una cultura del «conocimiento desinteresado". Creemos que la calificación de "desinteresado" alude justamente al hecho de no estar centrado en una meta fija e incuestionable. Los sofistas participan de una contienda que, reiteramos, parece guiada por un espíritu lúdico, el cual no se orienta a aprehender categorías ni a conquistar verdades universales; más bien, respondiendo a una motivación eminentemente práctica, está en continuo movimiento. Dicho con otras palabras, el fin del juego es solo la prolongación del juego mismo, y para ello es necesario rehuir de las certezas absolutas, reconocer la multiplicidad de perspectivas y admitir la provisionalidad de nuestras certidumbres.

\section{BiBLIOGRAFÍA}

\section{Obras de Nietzsche en alemán}

Sämtliche Werke: Kritische studienausgabe (KSA), 15 vol. (eds. Giorgio Colli und Mazzino Montinari), München, Berlin, New York, DTV, W. de Gruyter, 1988.

Werke: Kritische Gesamtausgabe, (KGW) II, 4 y II, 5 (eds. Giorgio Colli y Mazzino Montinari), München, Berlin, New York: DTV, W. de Gruyter, 1967 y ss.

Werke in drei Bänden (ed. Karl Schlechta), 3 vols,, München: Carl Hanser Verlag, 1966.

\section{Traducciones de la obra de Nietzsche}

Así habló Zaratustra, trad. Andrés Sánchez Pascual, Madrid, Alianza Editorial, 2000.

Aurora. Pensamientos sobre los prejuicios morales, trad. Germán Cano, Madrid, Biblioteca Nueva, 2000.

Crepúsculo de los ídolos, o cómo se filosofa con el martillo, trad. Andrés Sánchez Pascual, Madrid, Alianza Editorial, 1998.

El nacimiento de la tragedia, trad, Andrés Sánchez Pascual, Madrid, Alianza Editorial, 2000.

El pensamiento trágico de los griegos: escritos póstumos 1870-1871, trad. Vicente Serrano, Madrid, Biblioteca nueva, 2004.

Ecce homo, trad. Andrés Sánchez Pascual, Madrid, Alianza Editorial, 2000.

Escritos sobre retórica, trad. Luis Enrique Santiago Guervós, Madrid, Trotta, 2000.

Fragmentos póstumos, ed. Diego Sánchez Meca, Madrid: Tecnos, 4 vol., 2007-2010,

Humano, demasiado humano, II, trad. Alfredo Brotons, Madrid, Akal, 2007.

La ciencia jovial, trad. José Jara, Caracas, Monte Ávila, 1999.

La filosofía en la época trágica de los griegos, trad. Luis Fernando Moreno Claros, Madrid, Valdemar, 2003.

La genealogía de la moral, trad. Andrés Sánchez Pascual. Madrid, Alianza Editorial, 1998.

Los filósofos preplatónicos, trad. Francesc Ballesteros Balbastre, Madrid, Trotta, 2003.

Más allá del bien y del mal, trad. Andrés Sánchez Pascual, Madrid, Alianza Editorial, 2000. 
Obras completas, ed. Diego Sánchez Meca, Madrid, Tecnos, 4 vol., 2011-2016.

Sobre verdad y mentira en sentido extramoral, trad. Luis M. Valdés y Teresa Orduña, Madrid, Tecnos, 1990.

\section{Textos de consulta}

Acampora, C. D. (2003). «Demos Agonistes Redux. Reflections on the Streit of Political Agonism», en: Nietzsche-Studien, 32, pp. 374-390.

Birnbaum, A. (2004). Nietzsche. Las aventuras del heroísmo, México D.F.: F.C.E.

Bishop, P. (ed.) (2004). Nietzsche and antiquity: his reaction and response to the classical tradition. Rochester: Camdem House.

Brobjer, T. (2001). «Nietzsche's Disinterest and Ambivalence toward the Greek Sophists», en: International Studies in Philosophy, 23, pp. 5-23.

Brobjer, T. (2005). «Nietzsche's Relation to the Greek Sophists», en: Nietzsche Studien, 34, pp. 257-277.

Carrión, Ú. (2012). «La buena Eris. Reflexiones en torno a la lógica agonal en Heráclito y Nietzsche», en: Instantes y azares. Escrituras nietzscheanas, Buenos Aires, Año XII, Nº10, pp. 37-54.

Colomina, J. J. (2009). «Nietzsche y Heráclito», Éndoxa: Series Filosóficas, 23, pp. 177-190.

Colli, G. (2000). El nacimiento de la filosofía, Barcelona, Tusquets editores, p. 106.

Colli, G. (2000). Después de Nietzsche, Barcelona, Anagrama.

Cragnolini, M. (2003). Nietzsche, camino y demora. Buenos Aires: Biblos.

Diels, H. y Walter K. (1974). Die Fragmente der Vorsokratiker, Tomo I. Berlin: Weidman.

Eggers, C. y Victoria J. (1978). Los filósofos presocráticos, Tomo I. Madrid: Gredos.

Feitosa, C. et al. (orgs) (2006). Nietzsche e os gregos: arte, memória e educação. Assim falou Nietzsche $V$. Río de Janeiro: D \& A (etc).

Fernández, E. (ed.) (2012). Nietzsche y lo trágico. Madrid: Trotta.

García Gual, C. (2000). «Nietzsche, en el camino hacia los griegos», en: Revista de Occidente, Madrid, $\mathrm{N}^{\circ}$ 226, pp. 86-101.

Gorgias (1974). Fragmentos y testimonios. Buenos Aires: Aguilar.

Hawhee, D. (2002). «Agonism and Arete», en: Philosophy and Rethoric, Núm. 3, Vol. 35, pp. 185-207.

Hesíodo (1986). Los trabajos y los días, trad. Paola Vianello de Córdova. México D.F.: UNAM.

Innerarity D. (1998). "La seducción del lenguaje: Nietzsche y la metáfora», en: Contrastes, vol. III, pp. 123-145.

Karagiannis, N. y Wagner, P. (2008). «Varieties of Agonism: Conflict, the Common Good, and the Need for Synagonism», en: Journal of Social Philosophy, 39, pp. 323-339.

Krentz, P. (2002). «Fighting by the Rules: The Invention of the Hoplite Agôn», en: Hesperia, Vol. 71, No. 1, pp. 23-39.

Llinares, J. (2016). «Consideraciones sobre la guerra en Nietzsche», en: SÁnchez, N. (ed.), La guerra. Valencia: Pretextos, pp. 35-75.

Mann, J. (2003). «Nietzsche's Interest and Enthusiasm for the Greek Sophists», en: Nietzsche Studien, 32, pp. 406-428.

McIntyre, A. (1996). Historia de la ética. Barcelona: Paidós.

Müller, E. (2005). Die Griechen im Denken Nietzsches, München. Berlin, New York: DTV, W. de Gruyter5.

Nehamas, A. (2002). Nietzsche, la vida como literatura. Madrid: Turner, F.C.E.

Platón (1999). Crátilo, en: Diálogos, Tomo II, trad. J. L. Calvo. Madrid: Gredos.

Platón (1999). Eutidemo, en: Diálogos, Tomo II, trad. J. F. Oliveri. Madrid: Gredos.

Platón (1998). Sofista, en: Diálogos, Tomo V, trad. Néstor Luis Cordero. Madrid: Gredos.

Polo, L. (2005). Nietzsche como pensador de dualidades. Pamplona: EUNSA.

Robin, L. (1956) El pensamiento griego y los orígenes del espíritu científico. México: Uteha. 
Siemens, H. (2001). «Agonal configurations in the Unzeitgemäße Betrachtungen. Identity, Mimesis and the Übertragung of cultures in Nietzsche's early thought», en: Nietzsche Studien, 30, pp. 80-106.

Siemens, H. (2001). "Nietzsche's Agon with Ressentiment: Towards a Therapeutic Reading of Critical Transvaluation», en: Continental philosophy review, Norwell, Vol. XXXIV, pp. 69-93.

Siemens, H. (2009). «Umwertung: Nietzsche's "war praxis" in Ecce homo», en: Nietzsche Studien, 38, pp. 182-206.

Sloterdijk, P. (2000). El pensador en escena: el materialismo de Nietzsche. Valencia: Pre-Textos.

Sorosina, A. (2015). "O estatuto dos sofistas em Nietzsche», en: Estudos Nietzsche, Espírito Santo, vol. 6, n. 2, pp. 198-221.

Tuncel, Y. (2013). Agon in Nietzsche. Milwakee: Marquette University Press.

Universidad del Pacífico y

Úrsula Carrión Caravedo

Pontificia Universidad Católica del Perú

carrion_u@up.edu.pe

[Artículo aprobado para publicación en enero de 2018] 